\title{
PAHAM KEAGAMAAN DOSEN PENDIDIKAN AGAMA ISLAM UPN VETERAN YOGYAKARTA ${ }^{1}$
}

\author{
Achmad Habibullah \\ Puslitbang Pendidikan Agama dan Keagamaan | Balitbang dan Diklat Kemenag RI \\ Jl. MH Thamrin No.06 Jakarta Pusat | Email: Puslitbangpenda@yahoo.co.id
}

\begin{abstract}
The map of religious understanding among the Islamic Subject lecturers with respect to the issues of religion and State, religions and tolerance, religion and gender equality, religion and human rights relations has become important bearing in mind their strategic position in the process of transfer of knowledge and internalizing the religious moral values to their students. In the process, religious understanding enclosing their paradigm of thinking may enter and stain the religious understanding of their students' facing the conditions of more and more strengthened radical religious understanding. The mapping of religious understanding among the lecturers of Islamic Subject is a case study with a qualitative approach done at UPN Veteran Yogyakarta in 2013. Of the 10 lecturers of Islamic Subject in the university, 7 were interviewed. The study results showed that in general the Islamic Subject lecturers at UPN Veteran Yogyakarta embrace moderate Islamic understanding.
\end{abstract}

Keywords: Understanding, Religious, Lecturer, Islamic Subject

\section{Abstrak}

Pemetaan paham keagamaan dosen Pendidikan Agama Islam berkaitan dengan relasi agama dan Negara, relasi agama dan toleransi, relasi agama dan kesetaraan gender, dan relasi agama dan hak asasi manusia menjadi penting mengingat kedudukan dosen yang strategis dalam melakukan proses transfer pengetahuan dan internalisasi nilai-nilai moral religius kepada para mahasiswanya. Dalam proses tersebut, paham keagamaan yang membingkai paradigma pemikiran dosen dapat masuk dan mewarnai paham keagamaan mahasiswanya, yang dihadapkan pada kondisi semakin menguatnya pemahaman keagamaan yang radikal. Pemetaan paham keagamaan dosen Pendidikan Agama Islam ini mengambil studi kasus dengan pendekatan kualitatif pada UPN Veteran Yogyakarta yang dilakukan pada tahun 2013 lalu. Dari 10 dosen Pendidikan Agama Islam yang ada di universitas tersebut, 7 dosen berhasil diwawancarai. Hasil studi tersebut menunjukkan bahwa secara umum paham keagamaan dosen Pendidikan Agama Islam di UPN Veteran Yogyakarta masuk pada kategori paham Islam moderat.

Kata kunci: Paham, Keagamaan, Dosen, Pendidikan Agama Islam

\section{PENDAHULUAN}

Fenomena semakin merebaknya paham keagamaan Islam radikal di kalangan mahasiswa di perguruan tinggi umum diduga tidak hanya berkaitan dengan masuknya kelompok-kelompok keagamaan ke dalam kampus, seperti Hizbuttahrir Indonesia (HTI), Jama'ah Tabligh, Ikhwanul Muslimin, dan lain-

${ }^{1}$ Makalah ini pernah diseminarkan pada acara Diklat Jabatan Fungsional Peneliti Tingkat Lanjutan LIPI (10 - 15 Agustus 2014) pada tanggal 15 Agustus 2014 dalam versi Bahasa Inggris, dengan pembimbing Prof. Dr. Rihwanto. Makalah ini diangkat dari hasil penelitian saya sendiri tentang Pemahaman Dosen Pendidikan Agama Islam UPN Veteran Yogyakarta yang dilakukan pada bulan Juli 2013. Penulis mengucapkan banyak terima kasih kepada LIPI atas pembimbingan yang diberikan melalui narasumbernya, Prof. Dr. Rihwanto. Terima kasih yang tulus juga saya ucapkan kepada Kepala Puslitbang Pendidikan Agama dan Keagamaan atas pengarahan dan motivasinya, sehingga saya dapat menyelesaikan makalah ini.

Naskah diterima 21 Juni 2014. Revisi pertama, 10 Juli 2014. Revisi kedua, 25 Juli 2014 dan revisi terahir 4 Agustus 2014. 
lain, namun juga diduga berkaitan dengan paham keagamaan dosen Pendidikan Agama Islam itu sendiri.

Dosen Pendidikan Agama Islam, seperti dosen lainnya, memiliki peranan yang penting dalam pencapaian tujuan perkualiahan di kampus. Dalam hal ini, dosen dapat melakukan transfer pengetahuan melalui kontrol terhadap proses pembelajaran dan pendampingan secara individual. ${ }^{2}$ Dosen selain dapat melakukan transfer pengetahuan, juga dapat melakukan internalisasi nilai-nilai moral religius. ${ }^{3}$ Dalam proses internalisasi nilai-nilai moral dan pengetahuan keagamaan yang disampaikan tersebut, paham keagamaan dosen dapat masuk mewarnainya.

Melihat posisi dosen yang demikian itu, dan masih minimnya studi paham keagamaan dosen, menjadi sangat penting memaparkan hasil kajian paham keagamaan dosen Pendidikan Agama Islam terutama di perguruan tinggi umum pada makalah ini. Dalam makalah ini hanya mengangkat paham keagamaan dosen Pendidikan Agama Islam pada UPN Veteran Yogyakarta, sebuah perguruan tinggi umum berstatus swasta. Tulisan ini diangkat dari hasil penelitian Paham Keagamaan Dosen Pendidikan Agama Islam, kasus pada UPN Veteran Yogyakarta, yang dilakukan pada bulan Juli tahun 2013. Penelitian tersebut merupakan penelitian kasus, dengan pendekatan penelitian yang dipergunakan adalah penelitian kualitatif, di mana data digalih melalui wawancara. Responden yang dijadikan sumber data dan informasi sebanyak 7 dosen Pendidikan Agama Islam, Kepala Bidang Pendidikan dan Pengajaran, dan Pembantu Rektor II.

Paham keagamaan yang diangkat pada artikel ini mencakup empat aspek. Aspek pertama, relasi agama dan negara, berkaitan

${ }^{2}$ Lilik Nur Kholidah. 2010. Implementasi Strategi Pembelajaran Mata Kuliah Pendidikan Agama Islam pada Perguruan Tinggi Negeri di Surabaya

${ }^{3}$ Muhammad Murdiono. 2007. Strategi Internalisasi Nilai-nilai Moral Religius dalam Proses Pembelajaran di Perguruan Tinggi, Jurnal Cakrawala Pendidikan, LPM UNY dengan Pancasila sebagai ideologi negara, UUD 1945 sebagai sumber hukum tertinggi di Indonesia, dan sistem demokrasi yang diterapkan Indonesia. Aspek kedua, relasi agama dan toleransi, yang mencakup menghormati orang lain yang berbeda agama, menjalin hubungan dengan tetangga atau teman yang berbeda agama, dan pendirian rumah ibadah agama lain. Aspek ketiga, relasi agama dan kesetaraan gender, yang mencakup kedudukan laki-laki dan perempuan dalam Islam, relasi laki-laki dan perempuan dalam rumah tangga, dan kepemimpinan perempuan dalam politik atau pemerintahan. Terakhir, aspek keempat yang dikaji adalah relasi agama dan hak asasi manusia (HAM), yang mencakup konsepsi hak asasi manusia (HAM) dalam Islam, kesesuaian hak asasi manusia (HAM) dengan Islam, dan kebebasan beragama. Berdasarkan keempat aspek tersebut, dapat diketahui paham keagamaan seperti apa para dosen Pendidikan Agama Islam di UPN Veteran Yogyakarta, apakah termasuk kategori paham keagamaan sebagai Islam moderatkah, radikalkah, ataukah termasuk Islam liberal.

\section{Kajian Pustaka}

Paham keagamaan masyarakat Islam di Indonesia secara sederhana dapat dikategorikan menjadi tiga kelompok. Kategori pertama, paham keagamaan moderat, yang dianut oleh sebagian besar masyarakat muslim di Indonesia. Kategori kedua, paham keagamaan radikal, yang dianut hanya sebagian kecil masyarakat muslim di tanah air. Dan, kategori ketiga, paham keagamaan liberal, yang juga dianut hanya sebagian kecil masyarakat muslim Indonesia. Keberadaan ketiga corak paham keagamaan tersebut merupakan sebuah keniscayaan.

Dalam tradisi Islam, paham keagamaan moderat disebut juga sebagai ummatan wasathan, yaitu umat yang berada di tengahtengah, tidak terlalu ke kiri dan juga tidak terlalu ke kanan. Ciri-ciri dari ummatan 
wasathan (moderat) adalah memiliki cara berpikir yang seimbang (tawazun), menyeluruh (holistik), lurus dalam memahami sumber-sumber ajaran Islam, seperti Al-Qur'an dan Sunnah Nabi Muhammad saw., dan tidak memilah antara satu hukum dengan hukum yang lain untuk mendukung pandangannya. ${ }^{4}$

Paham keagamaan moderat di Indonesia pada umumnya sebagian besar dianut oleh organisasi keagamaan terbesar seperti Nahdlatul Ulama (NU), dan Muhammadiyah. Organisasi-organisasi keagamaan Islam lainnya yang juga memiliki paham keagamaan moderat adalah Mathlaul Anwar, Persis (Persatuan Islam), Al-Khairat, yang mempunyai kantor pusat di Sulawesi Tengah, dan beberapa organisasi keagamaan Islam lainnya. Secara umum, organisasi-organisasi keagamaan Islam tersebut memiliki paham keagamaan kategori moderat, namun mereka memiliki derajat sikap moderat yang berbeda-beda. Boleh dikatakan, organisasi keagamaan Persis menjalankan paham keagamaan yang moderat, tetapi relatif dinilai memiliki paham keagamaan yang lebih puritan dibandingkan dengan Mathlaul Anwar ataupun Al-Khairat.

Organisasi-organisasi keagamaan yang berpaham keagamaan moderat tersebut pada umumnya sebagai organisasi keagamaan yang bergerak di bidang dakwah dan pendidikan dan memiliki basis dukungan dari masyarakat. Oleh karena itu, gerakkannya lebih bersifat sosio-kultural, sehingga memiliki fleksibilitas yang tinggi dalam menghadapi perubahan masyarakat, sistem ekonomi, politik, dan perubahan budaya. Sikap keagamaan mereka sejauh ini sejalan dan mendukung pada kebijakan-kebijakan yang berdasarkan pada konstitusi Negara. ${ }^{5}$

${ }^{4}$ Zakky Mubarak. 2010. Ummatan Wasathan: Konsep Deradikalisasi Agama, makalah tidak diterbitkan.

5 Komaruddin Hidayat dan Ahmad Gaus AF. "Tipologi Gerakan Islam Kontemporer di Indonesia," dalam Komaruddin Hidayat dan Ahmad Gaus (ed.), 2005. Islam, Negara, dan Civil Society: Gerakan dan Pemikiran Islam Kontemporer, Jakarta, Paramadina. h. 488-505
Seperti paham keagamaan moderat, paham keagamaan radikal juga memiliki berbagai variasi yang menjadi kekhasannya. Namun demikian, paham keagamaan radikal ini dapat kita lihat pada titik pandang yang menganggap bahwa Islam tidak hanya mengatur masalah pribadi pemeluknya dengan Tuhannya, tetapi juga mengatur semua aspek kehidupan, seperti hukum, social, budaya, ekonomi, pendidikan, dan politik, dan memandang Islam sebagai ideology yang sempurna dibandingkan ideology-ideologi lainnya. Ciri utama yang mudah dilihat dari gerakan ini adalah adanya tuntutan penegakkan syariat Islam sebagai hukum positif, seperti pada peraturanperaturan daerah yang berdasarkan syariat Islam. Ciri utama lainnya adalah berusaha mendirikan Negara Islam (daulah Islam).

Organisasi keagamaan yang memiliki paham radikal di tanah air dapat dibagi menjadi dua, yaitu berbasis lokal dan transnasional. Organisasi keagamaan dengan paham keagamaan yang dapat disebut radikal seperti Front Pembela Islam (FPI), Majelis Mujahidin Indonesia (MMI), Forum Umat Islam (FUI), dan sebagainya. Sedangkan, gerakan keagamaan bersifat transnasional seperti Ikhwanul Muslimin (IM), gerakan Salafi, Hisbuttahrir Indonesia (HTI), dan lainnya. Gerakan keagamaan tersebut kini lebih bnyak bergerak menyebarkan ideologinya pada kalangan muda di kampus-kampus perguruan tinggi umum negeri maupun swasta. ${ }^{6}$

Kalau diibaratkan posisi, paham keagamaan moderat berada ditengah-tengah, paham keagamaan radikal cenderung ke posisi kiri. Sedangkan paham keagamaan liberal menempati ektrem kanan. Sama dengan kedua paham keagamaan sebelumnya, paham keagamaan liberal juga memiliki varian yang beragam. Namun untuk memudahkan menandainya dengan melihat beberapa gagasan dasar yang menjadi ciri utamanya.

${ }^{6}$ Noorhaidi Hasan. 2008. Laskar Jihad: Islam, Militansi, dan Pencarian Identitas di Indonesia Pasca Orde Baru. Jakarta, LP3ES.h. 56-57 
Ciri utama, paham keagamaan ini sangat tidak setuju dengan gagasan penyatuan agama dengan Negara (paham teokrasi). Yang kedua, sangat mendukung system demokrasi sebagai mekanisme untuk memilih pemimpin politik dan pemerintahan. Pemimpin politik ataupun pemerintahan bisa berasal dari masyarakat dan tidak harus dari tokoh agama. Berikutnya, kelompok paham keagamaan ini sangat mendorong terjadinya kesetaraan gender baik di area domestic maupun public. Kelompok paham keagamaan liberal ini juga menganggap bahwa setiap warganegara, baik muslim maupun non muslim mempunyai hak sipil yang sama dalam berbangsa dan bernegara. Terakhir, ciri utama lainnya adalah adanya kebebasan berpikir dengan membuka seluasluasnya pintu ijtihad dan kemajuan. ${ }^{7}$

\section{Profil Dosen Pendidikan Agama Islam di UPN Veteran Yogyakarta}

Dosen yang dijadikan responden sebanyak 7 (tujuh) orang, terdiri dari 6 laki-laki dan satu dosen perempuan. Pendidikan formal tingkat dasar sebagian besar di sekolah dasar negeri dan hanya dua orang yang mengikuti Madrasah Ibtidaiyah. Sedangkan di tingkat menengah sebagian menyelesaikan studinya di Madrasah Tsanawiyah dan satu program PGA 4 tahun. Dimana pada usia ini adalah usia pembentukan karakter dan pendidikan agama yang kuat dan sangat melekat.

Kemudian untuk jenjang tingkat atas hampir seluruh dosen belajar di Madrasah Aliyah dan sebagaian besar adalah Madrasah Aliyah yang berbasis pesantren dimana dalam sistem ini diterapkan pendidikan umum dan keagamaan secara formal di kelas-kelas juga diajarkan pendidikan agama yang bersifat tradisional seperti pengajian kitab kuning, pelatihan ceramah, bahasa arab aktif dan

7 Charles Kurzman, "Islam Liberal dan Konteks Islaminya," dalam Charles Kurzman, ed.. 2001. Wacana Islam Liberal: Pemikiran Islam Kontemporer tentang Isu-isu Global. Jakarta: Paramadina. h.xi lain-lain. Sebagaimana diketahui pendidikan model ini adalah tahap pematangan dalam mengkaji ilmu agama bagi seorang pelajar atau santri. Selain itu, lingkungan pesantren juga menanamkan keimanan dan ketakwaan yang tangguh ditunjang dengan pengembangan kepribadian dan toleransi bagi para santrisantrinya. Empat dari dosen yang ada meneruskan ke Fakultas Ushuluddin dan Filsafat UIN Yogyakarta dimana di fakultas ini dikembangkan pola berpikir yang kritis dan mendalam terhadap ilmu-ilmu agama dan filsafat. Sedangkan 3 dosen lainnya mengambil jurusan Pendidikan Agama Islam yang juga sangat mumpuni dalam didaktikmetodik pembelajaran agama yang praksis langsung dapat diterapkan di sekolah maupun perguruan tinggi.

Sebagaimana kita ketahui bahwa UIN Yogyakarta adalah mind setter pemikiran Islam di perguruan tinggi yang mana UIN Yogyakarta adalah pionir perguruan tinggi agama Islam di Indonesia. Sudah jelas kita ketahui bahwa UIN adalah pusat pemikiran dan peradaban sarjanasarjana muslim yang memiliki integritas tinggi baik dalam pengetahuan agama maupun pola pemikiran yang konstruktif dilengkapi wawasan dan paham keagamaan yang terbuka, kritis, dan moderat.

Selain pendidikan formal yang diraih, hampir keseluruhan juga mengikuti proses pembelajaran di lingkungan yang cukup baik. Dimana diketahui semuanya pernah belajar mengaji di majelis taklim, madrasah diniyah, madrasah-madrasah kelas sore dan pesantren. Hal ini bisa dimaklumi bahwa kultur Yogyakarta yang agamis dan sangat religius. Yogyakarta dengan basis terbesar adalah warga Muhammadiyah merupakan warga yang secara umum melek pengetahuan dan terbuka terhadap hal-hal baru diluar faham keagamaan yang sangat melekat. Namun juga penting menjadi catatan bahwa masyarakat Yogya umumnya adalah warga yang sangat memegang teguh kultur kejawaan (kejawen) sehingga budaya toleran dan tepo 
seliro adalah keabadian yang melekat dalam jiwa masyarakatnya.

\section{Mekanisme Rekruitmen Dosen Pendidikan Agama Islam ${ }^{8}$}

Dosen agama yang ada di UPN veteran Yogyakarta seluruhnya adalah dosen luar biasa yang diberikan surat tugas mengajar oleh universitas melalui surat keputusan pengangkatan (SK-Rektor). Kaitannya dengan Universitas adalah hak dan kewajiban seperti honorarium dan kewajiban mengajar seperti yang tertuang dalam SK tersebut. Mekanisme rekruitment dosen MKU PAI di UPN Veteran Yogyakarta ini berbeda dengan mekanisme yang ada. Rekruitmen yang dilakukan dengan sistem kolegial yang terjadi antara pihak prodi di masing masing jurusan atau fakultas dengan dosen Pendidikan Agama Islam yang terdahulu yang pernah mengajar di prodi itu, atau rekomendasi dari dosen Pendidikan Agama Islam yang sudah lebih dulu mengajar di UPN tersebut. Seperti diungkapkan oleh Drs. Teguh Pramono, M.Ag, bahwa latar belakang dosen itu ketok tular, berantai dari dosen yang senior ke yunior. Karena rekruitmen bersifat rekomendasi maka transparansi dan akuntabilitasnya hanya bersifat individual dan kolegial, karena tidak ada test untuk calon dosen sebagaimana lazimnya pengangkatan dosen pegawai negeri.

Setelah terjadi penunjukkan maka diajukan surat kesediaan kepada dosen Pendidikan Agama Islam yang diusulkan atau yang direkomendasikan kemudian dirapatkan di fakultas-fakultas tersebut. Biasanya pihak prodi merekrut dosen-dosen dari Universitas Islam Negeri (UIN) Yogyakarta dengan alasan bidang ilmu agama di UIN Yogyakarta sudah tidak diragukan lagi. Maka tak heran jika dosen MKU PAI di UPN Veteran Yogyakarta

${ }^{8}$ Data dan informasi diperoleh dari Kepala Bidang Pendidikan dan Pengajaran UPN Veteran Yogyakarta, Bambang Widiasmoro, S. Sos., MM. seluruhnya berasal dari dan mengajar di UIN Yogyakarta sebagai dosen.

Syarat-syarat yang harus dimiliki sebagai tenaga pengajar MKU Pendidikan Agama Islam adalah sebagai berikut: dosen Pendidikan Agama Islam harus memiliki ilmu agama yang mumpuni baik secara teori maupun kecakapan di masyarakat didukung latar belakang pendidikan agama Islam memiliki jabatan fungsional pendidikan, memiliki pengalaman mengajar yang tinggi dalam memberikan mata kuliah agama baik di UPN maupun perguruan tinggi lainnya yang ditunjukkan dengan sertifikat mengajar.

Selain itu, syarat kecakapan juga bisa dijadikan ukuran apakah dosen tersebut berhak diperpanjang kontrak mengajarnya atau tidak. Misalnya apakah dosen yang bersangkutan dapat memberikam kepuasan dalam mengajar yang dinilai mahasiswa. Maka pihak Universitas biasanya memberikan kuisioner terhadap kepuasan dosen-ini dilakukan kepada setiap dosen secara umum-sehingga jika ditemukan banyak komplain dari mahasiswa maka pihak kampus dapat mempertimbangkan apakah dosen yang bersangkutan berhak diperpanjang atau tidak kontrak mengajarnya.

Waktu pelaksanaan rekruitmen dosen PAI dilakukan setiap semester (di akhir semester), jika berakhir masa semester maka ada kesepakatan antara pihak fakultas di masingmasing prodi dengan dosen PAI apakah kontrak mengajarnya akan diperpanjang atau tidak. Bahkan keputusan ini bergantung pada dosen PAI tersebut dengan alasan kegiatan dosen-dosen tersebut diluar UPN. Kesepakatan ini terjadi secara kolegial semata karena proses rekruitmen itu sendiri tidak mensyaratkan perjanjian-perjanjian tertulis sebagaimana lazimnya. Jika terjadi kesepakatan maka baru kemudian pihak prodi mengusulkan ke fakultas untuk dirapatkan dan kemudian diajukan surat ke rektor untuk pengangkatan melalui surat resmi. Sementara pihak-pihak terkait yang terlibat dalam rekruitmen dosen MKU PAI adalah kepala prodi di masing-masing 
fakultas, sekretaris prodi, dekan dan Rektor sebagai pemberi surat pengangkatan melalui SK Rektor.

\section{Paham Keagamaan Dosen Pendidikan Agama Islam}

\section{Relasi Agama dan Negara}

Dalam mengukur paham keagamaan dosen Pendidikan Agama Islam (PAI) dilihat dari pandangan keseluruhan dosen yang menjadi objek sampling menunjukkan bahwa kesemuanya sangat menyetujui dan memandang bahwa Ideologi Pancasila adalah final sebagai ideologi Negara, dan UUD 1945 adalah satu-satunya dasar hukum tertinggi di negeri ini. Sementara demokrasi masih diyakini sebagai sistem politik yang masih relevan, meskipun banyak wacana yang menganggap bahwa demokrasi tidak berhasil diletakkan di Indonesia. Mereka memahami bahwa apa yang terdapat dalam Pancasila sudah sesuai dengan pola prilaku kehidupan islami seperti ketuhanan (uluhiyah) dalam setiap laku kehidupan seorang muslim. Konsep kemanusiaan yang adil dan beradab sangat sesuai dengan fitrah manusia dimana manusia menjadi poros utama dalam segala kehidupan sebagai makhluk ciptaan tertinggi. Persatuan Indonesia adalah sangat penting dalam pandangan Dosen PAI, dimana Negara ini dibentuk oleh rasa persatuan dan kebersamaan atas nama satu tujuan yaitu Indonesia merdeka. Maka tidak mungkin atas nama agama akan memisah-misahkan satu dengan yang lainnya hanya karena perbedaan agama semata. Islam menyakini bahwa perbedaan itu adalah rakhmat dari Tuhan semesta alam.

Sedangkan sila keempat adalah permusyawaratan yang dipimpin oleh hikmat kebijaksanaan dalam permusyawaratan dan perwakilan. Musyawarah adalah salah satu solusi dalam setiap permasalahan yang mana dalam dunia Islam bentuk urun rembug ini sangat ditekankan dalam Al-Qur'an (wasyawirhum fil al-ardl) untuk menyelesaikan setiap masalah yang ada dan untuk mencari titik mufakat demi tujuan bersama dengan segala resiko yang dihadapi bersama.

Konsep perwakilan dalam Pancasila juga sesuai dengan prinsip Islam dimana dalam sebuah tata kelola Negara atau masyarakat madani perlu ada pemimpin sebagai bentuk wakil masyarakat atau khalifah dalam menjalankan perintah-perinbtah Allah SWT. Oleh Karena itu semua bentuk keputusankeputusan yang dilakukan harus sesuai dengan keterwakilan masyarakatnya.

Dan, terakhir adalah keadilan sosial bagi seluruh rakyat Indonesia adalah perwujudan akhir dari semua nilai yan tertuang dalam pancasila yang juga adalah cita-cita Islam dalam menjalankan ibadah sebagai makhluk sosial di muka bumi. Keadilan tidak hanya diperoleh bagi kaum segelintir orang atau oleh mayoritas agama tertentu tapi harus dirasakan oleh semua kalangan tanpa memandang perbedaan suku, ras dan agama. Keadilan harus didapatkan oleh seluruh rakyat Indonesia.

Mengenai Demokrasi sebagai sistem politik Indonesia, semua dosen sepakat dengan sistem demokrasi yang diterapkan di negeri ini dengan alasan bahwa untuk sementara waktu hanya demokrasilah yang dapat memberikan jawaban bagi kelangsungan politik di tengah masyarakat yang majemuk. Demokrasi yang ada sudah sesuai dengan ajaran Islam atau paling tidak sudah mewakili esensi nilainilai Islam yang ada. Apalagi demokrasi yang ada dikuatkan dengan nilai-nilai lokal yang kuat dengan fondasi Negara yang diterapkan oleh founding father kita. Hanya saja para pemangku kebijakan harus lebih mengerti terhadap persoalan bangsa dan lebih sensitive terhadap penderitaan rakyatnya. Para wakil rakyat jangan lagi mementingkan ego pribadi dan kepartaian masing-masing tapi lebih mengutamakan kepentingan rakyatnya atau konstituennya. Ini juga adalah kritik utama terhadap nilai-nilai demokrasi yang masih jauh dari panggang, demokrasi sebagai formalitas 
sudah terlaksana tapi esensinya masih belum terasakan.

Mengenai isu-isu yang terjadi seperti gerakan-gerakan radikal yang terjadi di Indonesia yang mana muaranya adalah ingin menjadikan Negara Islam Indonesia. Sepakat semua dosen PAI UPN tidak setuju. Mereka menyakini bahwa mendirikan Negara Islam Indonesia adalah bukan suatu tuntutan dan sangat mustahil didirikan. Semua harus sadar bahwa Indonesia yang awalnya sebagai sebuah imagine (komunitas terbayang) kemudian menjadi sebuah Negara adalah sebuah perjuangan bersama yang tidak membawa unsur-unsur dan kepentingan sebuah kelompok, suku maupun daerah tertentu. Tapi Indonesia berangkat karena rasa ketertindasan yang dialami bersama dan rasa ingin keluar dari keterpurukan penjajahan Belanda.

Menyalurkan aspirasi melalui partai politik (baik partai Islam maupun non Islam) tidak bertentangan dengan syari'at. Demokrasi di Indonesia sendiri sudah mengakomodir seluruh aspirasi rakyatnya dengan boleh mendirikan partai baik yang berideologi nasionalis maupun Islamis selama visi-misi dan tujuan partai tersebut untuk kesejahteraan rakyat Indonesia dan dalam koridor demokrasi Pancasila. Ini dikuatkan dengan jawaban bahwa menggunakan kekerasn dengan cara apapun sangat tidak diperbolehkan untuk tujuan apapun termasuk atas nama agama.

Mengenai konsep Khilafah Islamiyah sebagai solusi yang harus ditegakkan di Indonesia, semua responden sepakat tidak setuju dengan penerapannya. Mereka menilai konsep khilafah adalah absurd karena tidak ada contoh khilafah islamiyah yang ideal dalam kehidupan Islam, sedangkan khilafah dalam era Empat Khalifah setelah jaman Rasulullah elan vitalnya adalah demokrasi dan musyawarah serta keadilan sosial. Adapaun konsep madinah yang diterapkan pada zaman Rasulullah dan digadang-gadang sebagai konsep tata Negara paling modern di jamannya adalah bukan sistem khilafah yang banyak didengung- dengungkan oleh sebagian kelompk muslim di Indonesia. Tidak ada konsep khilafah yang baku serta tidak tertuang dalam al-Qur'an mengenai prinsip-prinsip tersebut. Tapi yang mesti ditekankan adalah nilai-nilai persatuan, musyawarah dan mufakat, dan kepemimpinan yang baik.

Namun yang menarik jadi catatan mengenai hukum syari'at sebagai landasan hukum Islam apakah perlu diterapkan atau tidak dalam hukum Indonesia. Dua orang responden menekankan syari'at Islam dapat diberlakukan baik dalam UU maupun peraturan daerah (perda) yang ada, tapi tidak menjelaskan apakah syari'at itu berupa esensi atau syari'at secara formal. Jika dirunut ke atas responden tersebut adalah orang yang aktif di LDK dan kegiatan ROHIS baik sebagai pengajar maupun Pembina dan salah satunya pernah mengikuti halaqoh. Sedangkan empat responden lainnya tidak setuju dengan alasan hukum yang sudah ada sudah sangat refresentatif bagi kemaslahatan umat dan masyarakat Indonesia, hanya saja komitmen pemerintah dalam penegakkannya yang masih kurang.

Bagi mereka, jihad dalam konsepsi Islam tidak hanya berperang melawan musuh atau membasmi musuh yang jelas-jelas tidak sesuai atau tidak tunduk pada hukum syari'at. Jihad juga bisa dilakukan dengan memberikan wawasan dan penekanan bagi para pemimpin bangsa untuk mengambil sarisari dari syari'at Islam yang ada. Jihad adalah sebuah alat pacu yang diterapkan oleh agama sebagai pelecut semangat dalam setiap tindak laku kehidupan beragama. Misalnya, jihad melawan hawa nafsu atau pengendalian diri yang berimplikasi pada sikap toleran terhadap sesama. Jihad dalam mencari ilmu yang tentu memberikan implikasi pada kemajuan umat dan mencerdaskan bangsa dari kebodohan dan keterpurukan. Banyak cara yang dilakukan dengan mendasarkan diri pada konsep jihad itu sendiri. Jihad adalah patokan bagi seorang muslim untuk melakukan sesuatu sebagai grand 
design praktik-praktik keshalihan seorang muslim. Untuk itu pengertian jihad juga sudah dipahami dengan baik secara kontekstual oleh para dosen PAI dan diterapkannya dalam berdakwah dan dalam perkuliah di UPN Veteran Yogyakarta.

Darisisipartisipasipolitiksemuaresponden cukup aktif dalam event pemilu nasional meski di beberapa event pilkada kebanyakan tidak mengikutinya itu dikarenakan persoalan bahwa event pilkada tidak membawa dampak perubahan yang signifikan bagi perkembangan daerahnya.

Muti'ullah, M.Hum., salah satu dosen PAI yang menjadi responden, memberikan pandangan bahwa otonomi daerah dalam perkembangan politiknya tidak menciptakan iklim yang baik dalam perebutan kekuasaan di daerah. Pilkada hanyalah ajang perebutan kekuasaan bagi "raja-raja kecil" semata ketimbang pendekatan pelayanan kepada masyarakat. Perlu dibenahi sisi-sisi tujuan otonomi daerah itu sendiri. Untuk menjadi sauatu darah otonom bukan dilihat dari persebaran luas wilayah dan kepadatan penduduk tapi mampukah pemerintah setempat membangkitkan ekonomi dan kesejahteran di daerahnya itu dan mendekatkan pelayanan publik kepada msayarakat tertinggal. Kesiapan infrastruktur, pendidikan dan kesehatan adalah modal bagi berkembangnya suatu daerah otonom.

\section{Relasi Agama dan Toleransi}

Dari sisi toleransi seluruh responden hampir sama dalam menyikapi keberagaman dalam perbedaan beragama termasuk bagi umat muslim yang memiliki paham yang berbeda sekalipun. Sesuai dengan ajaran AlQur'an, Islam menghargai perbedaan bagi yang memiliki paham berbeda baik agama serumpun samawi maupun agama ardhi, sementara pemaksaan ajaran kepada yang lain adalah salah. La ikraha fi ad-din, Tidak ada paksaan dalam agama Islam.
Kerjasama dengan orang lain yang berbeda agama adalah sah karena manusia adalah makhluk sosial yang perlu memberikan sisi terbaik kemanusiaan meskipun ada beberapa dosen yang tidak mau terlibat lebih dalam soal urusan ketuhanannya masing-masing seperti saling memberi ucapan dalam perayaan natal dan sebagainya. Mereka beranggapan bahwa kami sangat menghormati perbedaan oleh karena itu kami tidak mau terlalu jauh mencampuri urusan agama lain. Sikap toleransi ini juga mereka lanjutkan dalam sikap dan ajakan dalam memberikan kuliah di UPN Veteran.

Semua responden setuju dengan tetap mau menjalin hubungan baik dengan tetangga atau teman yang non-muslim atau yang tidak satu aliran dengan mereka dan akan tetap mau bekerja sama dengan non-muslim dalam kehidupan keduniawian. Mereka memahami bahwa sebagai warga Negara, muslim dan nonmuslim memiliki hak yang sama sebagai warga Negara yang dilindungi Undang-Undang Dasar 1945 dan Pancasila dengan membiarkan muslim lain yang meyakini paham keagamaan yang berbeda dan dengan membiarkan nonmuslim untuk meyakini dan mempraktikkan kepercayaannya.

Dalam pertanyaan mengenai pendirian rumah ibadah semua dosen setuju dan menyepakatinya, ini dikarenakan latar belakang masyarakat kota Yogyakarta sangat plural dan beragam. Selain dari sisi sosio kultural dalam kultur kejawaan yang sangat terbuka dan longgar juga karena konsep ajaran tasamuh yang Islam terapkan bahwa beragama adalah hak individu yang tidak bisa diintervensi orang lain. Namun ada yang berpandangan bahwa pendirian rumah ibadah tentu tidak dapat seenaknya dilakukan tanpa konteks tertentu. Dalam membangun rumah ibadah tentunya ada syarat-syarat dimana di lingkungan sekitar rumah ibadah tersebut harus ada jamaah yang memadai. Mereka menganalogikan bahwa membangun sebuah masjid tentu harus terdapat 40 orang 
lebih laki-laki atau kepala keluarga di sekitar masjid tersebut. Begitu juga dengan pendirian gereja, pendiriannya bisa dimungkinkan jika di lingkungan pembangunan tersebut terdapat umat kristiani yang memadai.

Namun demikian, meskipun bila pembanguan rumah ibadah itu terlanjur didirikan responden tersebut akan membiarkannya. Ini berarti sikap toleransi antar beragama di Yogyakarta sangat baik. Secara kebetulan salah seroang dosen PAI adalah anggota Forum Komunikasi Umat Beragama (FKUB), Drs. Teguh Pramono, dimana ia merasa perlu mencoba memediasi jika terjadi isu-isu bahkan kerusuhan yang ada di dalam masyarakat. Yang kami lakukan adalah pendekatan dengan melakukan komunikasi dua arah sehingga FKUB dapat menganalisa masalah tidak hanya berasal dari satu pihak saja.

Tapi ada hal yang menarik bahwa ketika ditanya jika ada sekelompok non muslim yang melakukan ibadah di luar tempat ibadah yang semestinya, dua responden menanggapi dengan cara menasehatinya agar menghormati lingkungan. Ini mengidentikkan bahwa ada keresahan dan kekhawatiran bagi dirinya akan kegiatan tersebut. Padahal kegiatan ibadah umat islam sendiri tidak terfokus di rumah ibadah saja apalagi dengan kultur jawa (kejawen) di Yogyakarta sangat memungkinkan bagi agama apa saja sangat melekat dengan tradisi kejawaan. Lihat saja banyak upacara-upacara keagamaan yang dibalut adat setempat.

Selanjutnya, mengenai keterlibatan responden dalam hal ini dosen PAI di UPN Veteran dalam hal-hal yang sangat sensitif dan ekstrem sekalipun semua rata-rata responden tidak pernah melakukannya, misalnya melakukan penyegelan, aksi razia tempat hiburan malam, aksi razia warung nasi khususnya di bulan Ramadhan, pengusiran terhadap kelompok Syi'ah, Ahmadiyah atau memprotes dan menuntut dibubarkannya kelompok ajaran sesat. Kegiatan-kegiatan yang dilakukan hanyalah sebatas kemanusiaan semata dan tidak mengikuti kegiatan yang berkaitan langsung dengan kegiatan ibadah agama lain.

Dosen PAI di UPN juga dengan tegas melarang para mahasiswanya untuk mengikuti aksi razia tempat hiburan malam, aksi razia warung nasi khususnya di bulan Ramadhan. Ini mereka sadari bahwa masyarakat Yogyakarta bukanlah seperti kebanyakan kota lainnya yang mayoritas penduduknya muslim melainkan sangat beragam. Maka mereka anggap wajar jika ada beberapa warung yang buka di siang hari. Dalam hal ini, para dosen agama lebih menekankan pada aspek nilai ibadah puasa dan hukum ibadah puasa itu sendiri kepada mahasiswanya. Sehingga dapat diambil kesimpulan untuk menghindari sesuatu haruslah dibentengi dengan ajaran iman dan taqwa terlebih dahulu. Dengan penerapan nilai-nilai keimanan yang kuat dan pembinaan akhlak, meskipun banyak tempat-tempat berjualan makanan maka tidak mungkin umat Islam tergoda begitu saja.

\section{Relasi Agama dan Kesetaraan Gender}

Dalam Islam kedudukan perempuan dan laki-laki setara, tidak ada yang dibeda-bedakan dalam kedudukannya. Perempuan berhak untuk bekerja diluar rumah karena masingmasing berhak mengaktulisasikan dirinya sebagai manusia makhluk sosial.

Tugas kepala keluarga tidak hanya dalam urusan mencari nafkah tapi lebih pada imam yang sifatnya mengayomi, perlindungan, pengaturan dalam kehidupan keluarga. Sedangkan tanggapan mereka terhadap perempuan yang hanya boleh mengurus pekerjaan rumah tangga saja sama sekali tidak dibenarkan.

Semua responden sepakat bahwa perempuan dalam hal dan konteks tertentu perlu mencari nafkah jika; Pertama, dia sebagai single parent yang ditinggal suaminya. Kedua, dia bekerja dengan alasan membantu ekonomi keluarga dengan persetujuan suami. Ketiga, 
perempuan perlu aktualisasi diri khususnya lewat dunia kerja untuk menjalin silaturahim. Keempat, perempuan berhak menempuh karir dengan jenjang pendidikan yang telah diraihnya sehingga ilmu yang telah didapatkan tidak sia-sia. Salah seorang dosen mengatakan, selama tidak melalaikan tugas pokok sebagai seorang wanita/ibu/istri dan ada kesepakatan dengan suami maka tidak menjadi masalah.

Enam responden sangat setuju jika perempuan tidak hanya mengurus pekerjaan rumah tangga saja (ibu rumah tangga) melainkan juga boleh mencari nafkah, dan hanya satu orang responden mengatakan tidak setuju dengan alasan pribadi bahwa suami harus bertanggung jawab dalam pemenuhan kehidupan keluarga dan istri wajib membesarkan anak-anaknya dirumah.

Dalam urusan pendidikan anak, semua responden tidak setuju jika pendidikan lebih ditekankan pada anak laki-lakinya saja. Pendidikan wajib baik bagi laki-laki maupun perempuan, sebagai orang tua hanyalah memberikan yang terbaik bagi semua anakanaknya karena menuntut ilmu adalah kewajiban bagi setiap muslim dan muslimat. Alasan mereka bahwa menuntut ilmu adalah cara untuk mencapai kesejahteraan dan meninggikan derajat manusia dari makhluk lainnya.

Dalam perspektif gender yang lebih luas, semua responden tidak setuju perempuan memakai burka atau cadar, tapi setuju bila perempuan menggunakan jilbab sebagai penutup aurat sebagaimana yang lazim digunakan banyak perempuan di Indonesia. Cadar atau burqa adalah budaya yang banyak digunakan oleh perempuan-perempuan di Timur Tengah. Intinya adalah perempuan boleh menutup auratnya seperti bagian leher dan rambut, sehingga alangkah baiknya jika perempuan menggunakan jilbab dan lebih baik lagi itu dilakukan dengan kesadaran dan tanpa paksaan. Namun yang menarik dalam setiap pengajarannya, setiap dosen tidak memaksakan kepada mahasiswaya dalam pengajaran PAI untuk memakai jilbab.

Hanya saja jika ditanya apakah perempuan wajib ditemani mahramnya ketika bepergian sebagian besar menyebutkan setuju dengan tanpa alasan tertentu dan sisanya adalah raguragu. Jika dilihat masih ada garis demarkasi dalam pemberian ruang gerak perempuan dalam setiap kegiatannya. Secara umum para responden sangat toleran dan sangat pro gender namun dalam hal tertentu beberapa di antara masih ragu bahkan tidak setuju dengan tindakan-tindakan yang affirmatif emosional seorang kepala keluarga.

Mengenai keterlibatan perempuan dalam kegiatan politik baik dipilih maupun memilih adalah hak individu manusia merdeka yang tidak boleh dikekang bahkan semua responden tidak setuju dengan pernyataan bahwa kalau perempuan tidak boleh menjadi kepala Negara. Namun dalam hal-hal tertentu beberapa memberikan masukan dalam kepemimpinan wanita, adalah jika tidak ada pemimpin lakilaki yang refresentatif maka pemimpin wanita diperbolehkan. Karena laki-laki dalam pola kepemimpinan lebih menekankan aspek akal dan logika dalam setiap pengambilan keputusan dibandingkan perempuan yang lebih mengedepankan perasaan sehingga terkesan plin-plan dalam urusan pengambilan keputusan, apalagi menyangkut kepentingan publik.

\section{Relasi Agama dan Hak Asasi Manusia (HAM)}

Semua responden memandang HAM sesuai dengan Islam. Namun yang perlu jadi rekomendasi adalah Negara sebagai institusi harus benar-benar dalam penegakkannya. Termasuk Negara dalam penanggulangan konflik yang mengatas-namakan agama. Negara harus jeli melihat apa dan bagaimana konflik itu terjadi sehingga dalam penanggulangannya tidak menimbulkan konflik lanjutan. Tentu nilai-nilai HAM harus diperhatikan di dalamnya berbarengan dengan pemahaman-pemahaman nilai-nilai 
agama dalam penuntasannya sehingga semua agama bisa memahami bahwa perbedaan dan pertentangan dalam pendapat adalah lumrah dan tentu cara berkeyakinan yang berbeda pun adalah cara untuk menemukan kesejatian Tuhannya.

Kemudian apakah Negara ikut mengatur benar-tidaknya paham kelompok keagamaan tertentu, empat responden menyatakan "setuju" Negara harus berada ditengahnya dengan alasan bahwa sebagai kontrol dan pelaksana hukum Negara berhak memberikan penilaian terhadap sesuatu yang menggangu ketertiban umat yang ada. Misalnya, dalam konflik yang berlarut-larut mengenai sikap ahmadiyah yang tidak bisa diselesaikan umat maka Negara berhak memberikan penilaian, kebijakan bahkan sampai sanksi yang dilakukan. Sementara bagi yang menjawab "tidak setuju" menilai bahwa persoalan keimanan dan kepercayaan tidak bisa diganggu gugat, final. Benar-tidaknya suatu kelompok dalam menjalankan keyakinan adalah urusan pribadi (asasi).

Dari alasan yang menganggap setuju sebenarnya lebih pada aksi penanggulangan Negara dalam menghalau konflik termasuk konflik yang berkepanjangan akibat polemik paham yang berbeda dan susah mendamaikannya antar umat itu sendiri. Negara berhak melakukan pencegahan bahkan pengertian dengan memahami latar belakang dan kitab suci agama asalnya. Bukan pada memberikan batasan pada keyakinan tapi memberikan pengertian bahwa aliran yang dianutnya adalah sikap dan penodaan terhadap agama pandahulunya yang akan menimbulkan reaksi konflik yang dahsyat. Dalam hal ini tentu ada pihak-pihak terkait yang sesuai dengan jalurnya seperti Kementerian Agama sebagai instansi yang tepat mengurusi persoalan ini.

Mengenai Peraturan Bersama Menteri Agama dan Menteri Dalam Negeri Nomor 9 dan 8 tahun 2006 terkait pendirian rumah ibadah semua responden mengetahui isi peraturan tersebut. Namun ketika dilontarkan pertanyaan apakah peraturan bersama itu perlu dicabut satu responden tidak memberikan jawaban dan enam responden mengatakan tidak perlu dengan alasan jika dicabut hanya menimbulkan percekcokan dan permusuhan antar kelompok agama dan ada yang menjawab bahwa ada pihak yang berkompeten mengurus peraturan tersebut, bukan kewenangan individu-individu.

\section{PENUTUPAN}

Dari uraian tersebut di atas dapat ditarik beberapa kesimpulan. Pertama, paham keagamaan berkaitan dengan relasi agama dan Negara, kesemua dosen Pendidikan Agama Islam UPN Veteran Yogyakarta memandang bahwa Pancasila sebagai ideology Negara sudah final. UUD 1945 merupakan satu-satunya dasar hukum tertinggi. Demokrasi yang diterapkan Indonesia pada batas-batas tertentu sudah sesuai dengan ajaran Islam dan dapat memberikan jawaban bagi kelangsungan politik ditengah masyarakat Indonesia yang majemuk. Dosen Pendidikan Agama Islam UPN Veteran Yogyakarta juga tidak setuju terhadap gagasan mendirikan Negara Islam Indonesia dan tidak sepakat dengan konsep khilafah Islamiyah. Konsep jihad tidak hanya diartikan sebagai perang, namun juga diartikan sebagai jihad dalam mencari ilmu, mencerdaskan bangsa, memerangi kebodohan dan kemiskinan.

Kedua, paham keagamaan dosen berkaitan dengan relasi agama dan toleransi, kesemuanya sepakat bahwa ajaran Islam menghargai perbedaan agama ataupun keyakinan pemeluknya, yang ditunjukkan kesediaan dalam menjalin hubungan bertetangga dan berteman dan bekerjasama dengan orang yang berbeda agama, serta bersetuju adanya pendirian rumah ibadah non muslim di lingkungannya asalkan memenuhi peraturan yang berlaku.

Ketiga, paham keagamaan dosen berkaitan dengan relasi agama dan 
kesetaraan gender, kesemua dosen sepakat bahwa kedudukan laki-laki dan perempuan dalam ajaran Islam adalah sederajat, yang ditunjukkan dalam kesamaan hak dan kesempatan laki-laki dan perempuan dalam mendapatkan pendidikan, keterlibatan perempuan dalam politik dan pemerintahan, bahkan menjadi kepala negara atau presiden. Perempuan juga boleh berkiprah di luar ranah domestiknya dengan bekerja di luar rumah, asalkan perempuan tidak melupakan tugas pokok sebagai ibu bagi anak-anaknya dan sebagai istri bagi suaminya di rumah.

Terakhir, paham keagamaan dosen berkaitan dengan relasi agama dan Hak Asasi Manusia, kesemuanya sepaham bahwa hak asasi manusia sesuai dengan ajaran Islam. Dalam hal ini, negara diharapkan benar-benar dapat menegakkan hak asasi manusia. Pemerintah juga diharapka dapat tegas dalam menerapkan hukum untuk menegakkan hak asasi manusia bagi semua warganegara.

Dari keempat aspek keagamaan yang ditelaah tersebut, secara keseluruhan dapat diambil kesimpulan bahwa pada umumnya dosen Pendidikan AgamaIslam UPNVeteran Yogyakarta memiliki paham keagamaan Islam yang moderat. Kecenderungan paham dosen yang demikian itu sudah menjadi keyakinan pihak UPN Veteran Yogyakarta saat merekruitnya bahwa UIN Yogyakarta merupakan pusat pemikiran dan peradaban sarjana-sarjana muslim yang memiliki integritas tinggi, baik dalam pengetahuan agama maupun pola pemikiran keagamaan yang konstruktif, terbuka, kritis, dan moderat. Dan kecenderungan tumbuhnya paham keagamaan moderat itu sangat dimungkinkan dikarenakan masyarakat Yogyakarta yang religius masih memegang kuat kultur kejawaan, sehingga budaya toleran masih melekat kuat di masyarakatnya, termasuk para dosen Pendidikan Agama Islam yang juga sebagai pewaris adat istiadat kejawaan tadi.

\section{SUMBER BACAAN}

Abdullah, M. Amin (2006): Islam Studies di Perguruan Tinggi: Pendekatan IntegratifInterkonektif, Pustaka Pelajar, Yogyakarta

Azra, Azyumardi (2002): Pendidikan Islam: Tradisi dan Modernisasi Menuju Millenium Baru, Logos Wacana Ilmu, Jakarta

Fuaduddin, dan Bisri, Cik Hasan, Ed. (2002): Dinamika Pemikiran Islam di Perguruan Tinggi: Wacana tentang Pendidikan Agama Islam, Logos Wacana Ilmu, Jakarta

Hasan, Noorhadi (2008): Laskar Jihad: Islam, Militansi, dan Pencarian Identitas di Indonesia Pasca Orde Baru, LP3ES, Jakarta

Hidayat, Komaruddin, dan Gaus, Ahmad (2005): "Tipologi Gerakan Islam Kontemporer di Indonesia," dalam Islam, Negara, dan Civil Society: Gerakan dan Pemikiran Islam Kontemporer, Ed. Komaruddin Hidayat dan Ahmad Gaus, Jakarta, Paramadina, h. 488505

Kholidah, Lilik Nur (2010): Implementasi Strategi Pembelajaran Mata Kuliah Pendidikan Agama Islam pada Perguruan Tinggi Negeri, Surabaya

Kurzman, Charles (2001): "Islam Liberal dan Konteks Islaminya," dalam Wacana Pemikiran Islam Liberal: Pemikiran Islam Kontemporer tentang Isu-isu Global, ed. Charles Kurzman, Paramadina, Jakarta, h. xi

Mubarak, Zakky (2010): Ummatan Wasatthan: Konsep Deradikalisasi Agama, makalah tidak diterbitkan, Jakarta

Murdiono, Muhammad (2007): Strategi Internalisasi Nilai-nilai Moral Religius dalam Proses Pembelajaran di Perguruan Tinggi, Jurnal Cakrawala Pendidikan, LPM UNY, Yogyakarta

Muhaimin (2003): Wacana Pengembangan Pendidikan Islam, Pustaka Pelajar dan PSAPM, Surabaya

Nizar, Syamsul, dan Syaifudin, Muhammad (2010): Isu-isu Kontemporer tentang Pendidikan Islam, Kalam Mulia, Jakarta 